\title{
On the Mohist Critique of Other Pre-Qin Schools of Philosophy
}

\author{
Gao Huaping 高華平 \\ Professor of Research Institute of Philosophy, Jinan University, \\ Guangzhou, Guangdong, China \\ gaogaohuaping@163.com
}

\begin{abstract}
Mohism was the first ideology in the pre-Qin period to engage in open critique. Although it shared a common origin with Confucianism, Mohists criticized Confucianism by claiming that "in the teaching of the Confucians there are four elements sufficient to ruin the empire." Later students of Mohism went so far as to launch personal attacks against Confucius, the founder of Confucianism. Mohist discourse on the concepts of "universal love," "exalting worthiness," "reverence for ghosts," and "opposition to fatalism" mostly aimed at criticizing the philosopher Yang Zhu, especially his concepts of "action in one's self-interest," "not exalting worthiness," "disbelief in ghosts," and "resting content in the dispositions of one's inborn nature." Although, at the time of the Mohists, the schools of thought on yin-yang, diplomacy, legalism, names or logic, agriculture, and syncretism had not officially formed, some of their concepts and ideologies had already begun to emerge. As a result, the Mozi contains many criticisms of them.
\end{abstract}

\section{Keywords}

critique - Mohism - pre-Qin philosophy

As an important intellectual trend in philosophy in the pre-Qin period [before 221 BCE ], the Mohist school was intimately bound up with the Nine Trends and Ten Schools [jiuliu shijia 九流十家]. It came under fierce criticism by many scholarly circles in ancient China, including Mencius [372-289 BCE] and Xunzi 荀子 [ca. 313-238 BCE], who are commonly associated with Confucianism, 
as well as Yangzi 楊子 [395-335 вCE] and Zhuangzi 莊子 [ca. 369-286 вСE], who are commonly associated with Daoism. However, the terms Confucian Mohism [Ru-Mo 儒墨 or Kong-Mo 孔墨] and Yangzian Mohism [Yang-Mo 楊墨] were in common use at the time. Thus, as noted in the chapter "Overview of the Essentials [Yaolüe 要略]" in the Masters from Huainan [Huainanzi 淮南子], the notion that "Mozi studied the teachings of the Confucians and accepted Confucian thought"1 seems to have been profoundly influential.

Mohist thought has experienced a revival in the modern era. Granted, most scholars have limited their examination to comparisons of Confucianism and Mohism and discussions about their mutual contrasts and initial relationship. However, many scholars have offered in-depth discussions on the links between Mohism and other intellectual streams such as Daoism, the school of names or logic [ming 名], legalism [ $f a$ 法], and the school of yin-yang 陰陽. For example, with respect to the relationship between Mohism and Daoism, scholars believe that the Mohist concepts of "universal love" [jian'a $i$ 兼愛], "moderation in use" [jieyong 節用], and "opposition to offensive warfare" [feigong 非攻] stemmed from the Daoist concepts of "kindness" [ci 慈], "frugality" [jian 儉], and "fear of being the first in the world" [bugan wei tianxia xian 不敢為天下 先]. ${ }^{2}$ Later Mohist criticism of the pre-Qin philosophies was directed mainly at the tendency toward "sophistry" [guibian 詭辯] of the School of Logic (also called the school of names) and the Lao-Zhuang [laozhuang 老莊] tradition of Daoism. ${ }^{3}$ Regarding the relationship between Mohism and the school of logic, although some scholars deny the existence of the school of logic in the pre-Qin period, even more scholars affirm the link between the Mohism (especially late Mohism) and the school of logic, and some even contend that the school of logic originated in Mohism and was merely an offshoot of it. ${ }^{4}$ Regarding the relationship between Mohism and legalism, scholars believe that, although the Legalist advocacy of "discarding form and exalting essence" [qiwen shangzhi 棄文尚質] and centralizing power structures differs from the "exalting unity" [shangtong 尚同] and "valuing frugality" [guijian

1 Liu Wendian 劉文典, Huainan honglie jijie 淮南鴻烈集解 [Collected Explanations of the Huainanzi], coll. Feng Yi 馮逸 and Qiao Hua 喬華 (Beijing: Zhonghua shuju, 1989), 862-63.

2 Jiang Quan 江瑔, Duzi zhiyan 讀子㞎言 [Incoherent Words on Reading the Masters] (Shanghai: Huadong shifan daxue chubanshe, 2012), 69; Chen Zhu 陳柱, Moxue shilun 墨學 十論 [Ten Essays on Mohist Scholarship] (Shanghai: Huadong shifan daxue chubanshe, 2015), 117.

3 Feng Youlan 馮友蘭, Zhongguo zhexueshi xinbian 中國哲學史新編 [A New Account of the History of Chinese Philosophy] (Beijing: Renmin chubanshe, 2007), 1:467-72.

$4 \mathrm{Hu}$ Shi 胡適, Zhongguo zhexue dagang 中國哲學大綱 [An Outline of Chinese Philosophy] (Shanghai: Shanghai guji chubanshe, 1997), 135; Lü Simian 呂思勉, Xianqin xueshu gailun 先秦學術概論 [Introduction to Pre-Qin Scholarship] (Changsha: Yuelu shushe, 2010), 94. 
貴儉] theories of Mohism, an initial historical relationship can be found between them. ${ }^{5}$

Various studies have been conducted on the relationship between Mohism and the pre-Qin philosophies. Some of them are in depth, especially those that examine the relationship between Confucianism and Mohism, but they have had obvious shortcomings. First, these investigations have not been sufficiently comprehensive or systematic. They have tended to examine the relationship between Mohism and Confucianism, Daoism, the school of logic, or legalism, but rarely look at others. Second, these studies are mostly static comparisons of Mohist thought with other schools of thought; as such, they rarely examine the relationship between the Mohism and other schools of thought from the perspective of "letting the hundred schools of thought contend" [baijia zhengming 百家爭鳴]. In other words, scholarly criticism and ideological confrontation are perspectives that are often overlooked.

In light of this, in this article we provide a comprehensive and systematic review of the relationship between Mohism and the other pre-Qin philosophies from the perspective of Mohist criticism and contention and confrontation with other pre-Qin schools of thought. The goal is new explorations in the study of Mohism and other pre-Qin schools.

\section{The Relationship between Confucianism and Mohism}

Although Mohist criticism of Confucianism abounds, Mohism and Confucianism in fact have a common origin. According to the chapter "Overview of the Essentials" in the Huainanzi, "[Mozi] studied the teachings of the Confucians and accepted Confucian thought." Some scholars believe that in this sentence, "study" [xue 學] and "accept" [shou 受] do not infer a teacher-student relationship but, rather, portray the reading of Confucian texts. ${ }^{6}$ However, based on the author's textual research, a case can be made that Mozi 墨子 was born and died between $525-520$ вСE and 438 вСE, which is roughly twenty to thirty years earlier than Confucius [551-479 BCE]. The "Biographies of Mencius and Xun Qing [Mengzi Xun Qing liezhuan 孟子荀卿列傳]" in the Records of the Grand Historian [Shiji 史記] state: "Some say he was contemporaneous with

5 Chen Zhu 陳柱, Zhuzi gailun: Wai yi zhong 諸子概論: 外一種 [Introduction to the Pre-Qin Philosophers: An Additional Version] (Shanghai: Huadong shifan daxue chubanshe, 2015), 320.

6 Chen Zhu, Zhuzi gailun, 137 . 
Confucius, while others say he lived sometime after Confucius." ${ }^{\text {T }}$ The lifespans given for Mozi here both hold water. It is also entirely possible that Confucius lived from $55^{2}$ BCE to 479 BCE and that Mozi once studied with Confucius. ${ }^{8}$

In addition, according to the relevant studies, much of Mohist thought can be found to have originated with Confucius and related Confucian ideology. For example, some scholars have argued, "The sole doctrine of Mozi was 'universal love."'9 However, Confucius spoke many times on the theme. In the chapter "Studying and Practicing [Xue'er 學而]" in the Analects, Confucius is recorded as admonishing his followers thus: "When in front of your parents, be filial to them; when outside the home, show respect to your male peers; speak little, but when you do, be honest and credible; show fraternity to the people and get close to those who have empathy."10 Here, "showing fraternity to people" in general is originally written fan'ai 沉愛, which can also be read as equivalent to jian'ai. The chapter "There Is Yong [Yongye 雍也]" also speaks of "providing wide-ranging benefits to the people and helping them live well."11 These quotations demonstrate that a concept of universal love was in fact espoused by Confucians. Moreover, this ideological proposition was actually put forward before Mozi and should be seen as the origin of Mohist doctrine. Scholars in the modern era, such as Zhang Caitian 張采田 [1874-1945] and Chen Zhu 陳柱 [1890-1944], have argued that not only universal love but also "exalting worthiness" [shangxian 尚賢], "opposition to fatalism" [feiming 非命], "moderation in use," and "perceptive ghosts" [minggui 明鬼] can be found to have originated in Confucianism, contending that "Confucius is the one who taught and transmitted these ideas," which "were not carried forward until the time of Mozi."12

Thus, it can be argued that Mohism originated in Confucianism and that their basic ideas are closely bound up with one another. That being the case, why would Mozi and Mohists criticize Confucius and his followers?

7 Sima Qian 司馬遷, Shiji 史記 [Records of the Grand Historian], comm. Pei Yin 裴駰, Sima Zhen 司馬貞, and Zhang Shoujie 張守節 (Beijing: Zhonghua shuju, 2014), 7:2855.

8 Gao Huaping 高華平, “Mozi shengzunian xinkao 墨子生卒年新考 [New Studies on the Dates of Birth and Death of Mozi]," Jiangxi shifan daxue xuebao 江西師範大學學報, no. 5 (2018).

9 Chen Zhu, Zhuzi gailun, 312.

10 Zhu Xi 朱喜, Sishu zhangju jizhu 四書章句集注 [Collected Commentaries on the Four Books Arranged in Sections and Sentences] (Beijing: Zhonghua shuju, 1983), 49.

11 Zhu Xi, Sishu zhangju jizhu, 91.

12 Chen Zhu, Zhuzi gailun, 309-10. See also Wang Pinzhen 王聘珍, Da dai liji jiegu 大戴禮 記解詁 [Explanations and Philological Assessments of the Ritual Record of the Elder Dai], coll. Wang Wenjin 王文錦 (Beijing: Zhonghua shuju, 1983), 155-57. 
Could it be, as some scholars claim, that "the meaning of $r u$ as 'having integrity' or 'having techniques of the Way' does not exclusively refer to Confucianism," that "Mozi was not anti-Confucian," and that the "opposition to Confucianism" discussed in the Mozi "was not the original idea of Mozi"? 13 The reasons that this is not the case are as follows.

First, according to the chapter "Overview of the Essentials" in the Huainanzi, as well as accounts in the Mozi, the anti-Confucian tendency in Mohism was not a repudiation of all points of view in Confucianism. Rather, it was merely disapproval of some of the Confucian ideas and methods. The chapter says that Mozi believed that "Their rituals were complicated and tedious; expensive funerals cost considerable amounts of money and throw the people into poverty; long-term mourning hurts lives and hinders political affairs." ${ }^{14}$ What Mozi opposed was in fact some of the Confucian rites and rituals, not the Confucian ideology as a whole. In the chapter "Against Confucianism II [Feiru xia 非儒下]," what is criticized is in fact "long-term mourning," "stubborn insistence on fatalism," "overly elaborate rites and music," and "the man of integrity [junzi 君子] emulating his predecessors and not innovating," as well as the concepts that "the man of integrity who is victorious in battle does not chase deserters." 15 Some of the behavior of Confucius also comes under fire. However, there is no criticism of concepts that are core to the Confucian belief system, such as humaneness [ren 仁], dutifulness [ $y i$ 義], rites [ $l i$ 禮], wisdom [ $z h i$ 智], trustworthiness [xin 信], and sageliness [sheng 聖].

Further, some of Mozi's views that were critical of Confucianism probably concerned particular situations at specific times and places, a point that Mozi once made. The chapter "Inner Assortment of Parables I: The Seven Tactics [Neichu shuo shang qishu 內儲說上七術]" in the Han Fei zi 韓非子 records that, during the time of Duke Huan of Qi 齊桓公 [r. 685-643 BCE], "The domain of Qi regularly held elaborate funerals. Cotton and silk were used to dress the deceased, while timber was used for the coffins. Duke Huan was very concerned about this, and informed Guan Zhong of his concerns."16 This shows that elaborate funerals and lengthy mourning had already become customary during Duke Huan's reign. Mozi's criticism of these practices may have also been directed at the social customs of the time; the phrase "upon entering a

\footnotetext{
13 Chen Zhu, Zhuzi gailun, 137.

14 Liu Wendian, Huainan honglie jijie, 862-63.

15 Sun Yirang 孫詒讓, Mozi jiangu 墨子閒詁 [Inquiries and Interpretations of Mozi], coll. Sun Qizhi 孫啟治 (Beijing: Zhonghua shuju, 2001), 286-306.

16 Liang Qixiong 梁啟雄, Hanzi qianjie 韓子淺解 [A Brief Interpretation of the Han Fei zi] (Beijing: Zhonghua shuju, 2009), 238.
} 
country, one must choose the most pressing matter to advise on,"17 for example, was not merely targeted at Confucian ideology. In other words, there was no fixed pattern in which Mozi criticized particular ideas or doctrines in particular circumstances. His criticism of Confucian thought and behavior only expressed disapproval of extravagance and waste, as well as fatalistic discourse, both of which he saw as caused by the excessive practice of rites. Moreover, this was still proposed under the premise of "a country in poverty" [guo pin 國貧] whose leaders were guilty of "loving music and indulging in liquor." In the context of "a country in poverty," not only Confucianism but indeed any support for red tape that was extravagant and wasteful became a target of "opposition" [ $f e i$ 非] by Mohists. In the context of the time, Confucianism used its status as a "prominent area of learning" [xianxue 顯學] to promote elaborate funerals, lengthy mourning, rituals and music, and the concept of "divine will" [tianming 天命]. Because Mozi wanted to criticize the extravagance of the world at that time, it is likely that some social customs were labeled as Confucian. As a matter of course, he criticized what he perceived as the mistakes of Confucianism and attempted to expose inherent contradictions in the words and deeds of its founder, Confucius.

In addition, at the time of Confucius and Mozi, the scholarly discourse in ancient China was still developing. It was commonplace for the various schools to argue with and criticize one another, and this occurred even between Confucius and his disciples. The "Biographies of Confucius's Disciples [Zhongni dizi liezhuan 仲尼弟子列傳]" in the Records of the Grand Historian states: "Zilu has a simple-minded temperament. He is brave, strong-willed, and forthright. He wears a rooster hat on his head and carries a sword decorated with boar skin. He once bullied Confucius."18 However, this "bullying" should not be understood as physical assault but, rather, a kind of unceremonious attack on Confucius's way of thinking.

The “Yang Huo 陽貨” chapter in the Analects says that Zai Wo 宰我 [522-458 BCE ], a prominent disciple of Confucius, had a completely negative attitude toward Confucian funeral rites. He believed not only that "sustained periods of mourning hurt the living and hinder ordinary business" but also that the practice "threw the system of rites into chaos" [lihuai 禮壞] and "caused a collapse in the cultural order" [yuebeng 樂崩]..$^{19}$ Essentially, he saw it as contributing directly to "the wrecking of rituals and the destruction of music." Thus, some scholars argue that Zai Wo "can almost be considered a member of the Mohist

\footnotetext{
17 Sun Yirang, Mozijiangu, 475.

18 Sima Qian, Shiji, 2664.

19 Zhu Xi, Sishu zhangjujizhu, 181-82.
} 
school."20 In fact, the chapter "Against Confucianism" in the Mozi is critical of behavior that violates the tenets of humaneness, dutifulness, loyalty, and trustworthiness advocated by Confucius. Although the chapter "Interrogating Mohists [Jiemo 詰墨]" in the Anthology of the Kong Family Masters [Kongcongzi 孔叢子] defended this charge, this does not change the fact that Confucius's behavior was questioned and criticized at that time.

Moreover, this kind of questioning and controversy often does not come from schools of thought other than Confucianism but, rather, from Confucius's own disciples. The "Yang Huo" chapter in the Analects also says that "Gongshan Furao was entrenched in the territory of Bi and planning a rebellion. He summoned Confucius and Confucius prepared to go.... Bi Xi summoned Confucius, and Confucius prepared to go." Zi Lu 子路 [542-48о BCE], one of Confucius's best-known and most faithful disciples, expressed his disapproval of these events. ${ }^{21}$ The primary reason that Confucius's behavior often contradicted the kind of morality and justice he promoted, and gave rise to doubts, criticism, and ridicule by others - including his own students - might be his own contradictions but also the irreconcilable conflict between the moral principles that Confucius insisted on and the political ideals he pursued. Even his disciples often criticized his thoughts, propositions, words, and deeds. Therefore, it is not impossible or completely incomprehensible for Mozi - who "studied the teachings of the Confucians and accepted Confucian thought" - to write an anti-Confucian chapter.

Furthermore, even though Confucius, as the founder of Confucianism, studied under Laozi, the founder of Daoism, he ultimately parted ways with the Daoists, giving up the concept of "unworked wood" [ $p u$ 樸] for "refined form" [wen 文], rejecting Daoist's simple and unadorned ways and worshipping King Wen 周文王 [r. 1105-1056 вСе], King Wu 周武王 [r. 1050-1043 вСE], and the Duke of Zhou 周公 [d. 1033 BCE]. The chapter “Xian Asked [Xianwen 憲問]” in the Analects recounts: "Someone said, 'What do you think of repaying a wrong with kindness?' Confucius said, 'How, then, can kindness be repaid? To repay a wrong, one uses one's moral integrity. To repay kindness, one uses kindness."”22 “Using kindness to repay a wrong” [yide baoyuan 以德報怨] appears in chapter 62 of the received version of the Laozi. Here, the Analects states this as "someone said" [huoyue 或曰]. In his Later Notes on the Analects [Lunyu hou'an 論語 後案], Huang Shisan 黄式三 [1789-1862], an eminent scholar in the Qing dynasty [1616-1911] points out that the concept of "using kindness to repay a

\footnotetext{
20 Chen Zhu, Zhuzi gailun, 193.

21 Zhu Xi, Sishu zhangju jizhu, 177-78.

22 Zhu Xi, Sishu zhangjujizhu, 158.
} 
wrong" is in fact Laozian in origin. ${ }^{23}$ Thus it is evident that Confucius's phrase "to repay kindness, one uses kindness" is an ideological challenge to Laozi. In light of the fact that Confucius and his disciples were apt to criticize their teacher directly, for Mozi - who studied the teachings of the Confucians and accepted Confucian thought - to express anti-Confucian sentiments is conceivable. Naturally, perhaps only the first half of "Against Confucianism II" in the extant Mozi contains Mozi's own views, whereas the second half should be seen as a product of post-Qin Mohists. This point is elaborated below.

The chapter "Gong Meng 公孟" in the Mozi contains the criticism that "the teaching of the Confucians has four elements that are sufficient to ruin the empire," which are "the Heavens are unintelligent, and ghosts do not have spiritual powers," "holding elaborate funerals and mourning for the dead for long periods of time," "being accustomed to song and dance," and "life is preordained." ${ }^{24}$ In the extant documents, criticism of Confucianism by the Mohists is fully reflected in the chapter "Against Confucianism" in the Mozi. However, although Mozi theoretically and logically may have been against Confucians and Confucius, this cannot be interpreted as Mozi having been against Confucians and Confucius in reality. To determine whether Mozi was in fact against Confucians and Confucius, one needs to examine both the theory and logic and, more importantly, whether the historical sources have a basis for this interpretation.

The chapter "Against Confucianism II" in the Mozi is remarkable in terms of its structure and content: the first half is anti-Confucian, while its second half is anti-Confucius. Note also that, one paragraph after "Confucians say," it reads: "Those who insist that life is preordained contend that ..." Being out of harmony with the rest of the passage, it appears to have been erroneously transplanted from the chapter "Against Fatalism [Feiming 非命]." The first half of the chapter begins with "Confucians say" and "and also say." First, it describes the views of Confucians, and then it criticizes each of the views one by one. The second half of the chapter begins "All techniques of the Way and learning have their roots in humaneness" and censures the "mutual contradictions" of "the

\footnotetext{
23 Cheng Shude 程樹德, Lunyu jishi 論語集釋 [Collected Annotations on the Analects], coll. Cheng Junying 程俊英 and Jiang Jianyuan 蔣見元 (Beijing: Zhonghua shuju, 199o), 1313 .

24 Sun Yirang, Mozi jiangu, $45^{8}$.
} 
conduct of Confucius" and his support for humaneness. ${ }^{25}$ Thus, many modern scholars have argued that "Against Confucianism I," from "All techniques of the Way and learning have their roots in humaneness" onward, that argues against the conduct of Confucius, was already compromised by later generations that they cannot reflect Mozi's thought. For instance, the renowned scholar and Mozi specialist Wu Yujiang 吳毓江 [1898-1977] stated that the segment “differs remarkably from the argument presented in the preceding text, and does not resemble a [coherent] text, and so we suspect that is an insertion or alteration made by later generations, and that it cannot be dated to the formative period of the Mozi." 26

The chapter "Boundless Discourses [Silun xun 汇論訓]" in the Huainanzi gives the following remarks on the dispute between Confucianism and Mohism: "Singing to stringed instruments and dancing to drums so as to make music; turning, bestowing, diminishing, yielding so as to practice the rites; having lavish burials and lengthy mourning so as to send off the dead: These were established by Confucius, but Mozi opposed them."27 This shows that, at the time of Confucius and Mozi, Confucius's most influential ideas were those on music, rites, and funerary and mourning practices, and the first half of the chapter "Against Confucianism II" is aimed precisely at these aspects of Confucianism.

It could be argued that Mohist criticism of Confucianism - either by Mozi or by others at the time of Mozi - was entirely a criticism of Confucius's scholarly views and that no trace can be found of a personal attack on Confucius. Thus, the received version of the "Gong Meng" chapter in the Mozi records a lengthy conversation between Mozi and the Confucian Gong Meng, in which Mozi criticizes various aspects of Confucian thought. However, the thrust of this criticism is identical to that in the "Against Confucianism" chapter, merely limited to the contradictions of Confucianism, such as that "poverty, wealth, longevity, and untimely death are preordained," that elaborate burials and long-term mourning must be carried out, and that "sacrificial rites are essential learning" despite an absence of belief in ghosts. ${ }^{28}$ These are not attacks on Confucius as an individual. The situation is similar in the chapter "Geng Zhu

\footnotetext{
25 Sun Yirang, Mozi jiangu, 286-306.

26 Wu Yujiang 吳毓江, Mozi jiaozhu 墨子校注 [The Mozi with Collated Commentaries], coll. Sun Qizhi 孫啟治 (Beijing: Zhonghua shuju, 2001), 433.

27 Liu Wendian, Huainan honglie jijie, 524. Translation modified from John S. Major, Sarah A. Queen, Andrew Seth Meyer, and Harold D. Roth, The Huainanzi: A Guide to the Theory and Practice of Government in Early Han China (New York: Columbia University Press, 2010), 13:9. - Trans.

28 Sun Yirang, Mozi jiangu, 454, 456.
} 
耕柱" in the Mozi. In fact, Mozi believed that "that which is reasonable and cannot be changed" should be "praised." 29

However, by the mid- to late Warring States period [ $\left.475^{-221 ~ B C E}\right]$ significant changes had occurred in the criticism of Confucian thought by later followers of Mohism. What was originally scholarly criticism had turned into condemnation of Confucianism and even personal attacks on Confucians themselves. According to the chapter "Equalizing Assessments of Things [Qiwu lun 齊物 論]" in the Zhuangzi 莊子, the dispute between Confucianism and Mohism had reached a stage in which "each side would affirm what the other side denied and deny what the side party affirmed." 30 More importantly, in the second part of the chapter "Against Confucianism II," the Mohists called Confucius by his first name, Qiu 丘, and accused him of being inhumane and undutiful. Evidently, their merciless mocking went beyond the criticism in the Zhuangzi and exhibited a Legalist tone resembling the Han Fei zi.

In the early stages, Mohist criticism of Confucian thought was mainly targeted at Confucian support for song and dance, performative rites, and elaborate funerals and long-term mourning practices as manifestations of filial piety. The following chapters of the Mozi contain critiques of this conduct: “Moderation in Use [Jieyong 節用]," “Moderation in Funerals [Jiezang 節葬]," and "Condemning Music [Feiyue 非樂]." "Condemning Music" defines the following standard for the behavior of a "humane man" [renren 仁人]: "[He] must strive for the benefit of the empire and seek to eliminate all calamities throughout it." Thereafter it is written: "There are three kinds of suffering among the people: the hungry cannot get food, the cold cannot get clothes, and the working cannot get rest." ${ }^{31}$ Here, Mozi is not so much criticizing Confucian music theory as he is criticizing the extravagant and hedonistic lifestyle of the upper class at the time. Likewise, it is not so much an academic criticism of the social ethos and artistic viewpoints of the time as it is a kind of social criticism of these topics.

The chapters "Moderation in Use," and "Moderation in Funerals III" seem to advocate the Mohist concept of valuing frugality. However, the structure of the Mozi requires that every topic receive supportive and critical treatment, and the topic of Confucians' "excessive rites" [ fanli 繁禮] is no exception. The "Bibliographic Treatise [Yiwenzhi 㙯文志]" in the History of the Han [Hanshu 漢書] says that, in order to emulate the ancient kings Yao 堯, Shun 舜, Yu 禹,

\footnotetext{
29 Sun Yirang, Mozi jiangu, 46o.

30 Guo Qingfan 郭慶藩, Zhuangzi jishi 莊子集釋 [Collected Annotations on the Zhuangzi], coll. Wang Xiaoyu 王孝魚 (Beijing: Zhonghua shuju, 2012), 63.

$31 \quad$ Sun Yirang, Mozi jiangu, 251.
} 
Wen, and Wu, followers of Mohism lived moderate and frugal lives in "cogongrass-roof structures with rafters made from gathered wood" and that "upon seeing the advantages of living frugally became opposed to proprieties." ${ }^{2}$ In other words, contrary to the positive arguments of Mohism on moderation in use, moderation in funerals, and valuing frugality, the Mozi actually presents a condemnation and criticism of Confucian rites, perceiving them as unnecessarily complicated expressions of propriety during social interactions.

Like Mozi's criticism of Confucian views on music, Mohist criticism of Confucian ritualism is not a theoretical criticism but mainly a criticism of the social effect of what is seen as the unnecessarily complicated expressions of propriety and tediously elaborate rites advocated by Confucians. Thus it is a social criticism that contends that "the rites are excessive" and that "the increased costs are not in the interests of the people." Further, although Confucius took rites, rituals, and propriety very seriously in an effort to reinstate the "rites of Zhou" [Zhou li 周禮], when Lin Fang 林放 from Lu [1043-255 BCE] asked about their essential nature, he responded, "When it comes to general etiquette, it is better to be frugal than to be lavish; when it comes to funeral rites, it is better to be sorrowful than to be extravagant." ${ }^{33}$ That is, Confucius did not blindly emphasize complexity and embellishment of ritual forms. Therefore, Mozi's criticism of Confucian ritualism could not have been specifically directed at Confucius himself; it should have been directed at "vulgar Confucians" [suru 俗儒] who saw official rules and formalities as eye-catching images to project to the outside world.

The academic criticism of Confucianism by Mohists in the later period would have occurred mainly in the Qin [770-207 BCE] state during the mid- to late Warring States period. Opinions differ as to when Mohism was introduced in Qin. The Chinese-American scholar Ping-ti Ho 何炳棣 [1917-2012] believed that it occurred when Duke Xiao of Qin 秦孝公 [r. 361-338 BCE] appointed Duke Xian of Qin 秦獻公 [r. 384-362 BCE] before the reforms of Shang Yang 商 鞅 [ca. 395-338 вСе]. It is reasonable to claim that a large number of Mohists could have gathered in Qin before Duke Xiao authorized these reforms. ${ }^{34}$ The chapters "Biding One's Time [Shoushi 首時]," “Doing Away with Selfishness

32 Chen Guoqing 陳國慶, ed., Hanshu yiwenzhi zhushi huibian 漢書㙯文志注釋彙編 [Commentaries and Elucidations on the Bibliographic Treatise of the History of the Han] (Beijing: Zhonghua shuju, 1983), 144-45. Zhu Xi, Sishu zhangju jizhu, 62.

34 He Bingdi 何炳棣, “Guoshi shang de 'dashi yinyuan' jiemi: Cong chongjian Qin-Mo shishi rushou 國史上的“大事因緣’解謎 - 從重建秦墨史實入手 [Revealing the ‘Causality of Major Events' in Chinese History: Starting with the Reconstruction of the Historical Facts Surrounding the Mohists in Qin]," Guangming ribao 光明日報, June 3, 2010. 
[Qusi 去私]," and “Rooting Out Bias [Quyou 去宥]” in Master Lü's Spring and Autumn Annals [Lüshi chunqiu 呂氏春秋] contain records about Tian Jiu 田 鳩, Xiezi 謝子, Tang Guguo 唐姑果, and Fu Tun 腹黄 - described as “Mohists from the East" and "Mohists of Qin" - meeting King Hui of Qin 秦惠王 [r. 337-311 BCE]. This demonstrates how active the Mohists were in Qin at that time. Mohists presumably gathered there because of Qin's promotion of the "rule of law" [ fazhi 法治] after the enactment of Shang Yang's reforms. Granted, Shang Yang's policies were tyrannical. People were punished for being related to or friendly with someone who had broken the law. Rewards were also given for reporting traitors and recounting military exploits. Thus, they did conflict with the Mohist principle of universal love and the condemnation of offensive warfare. However, the reforms also had a utilitarian purpose. They encouraged agricultural production, rewarded farming and weaving, advocated the banning of the Book of Songs [Shijing 詩經] and the Book of Documents [Shujing 書 經] and other Confucian elements seen as detrimental to the interests of the empire, called the "six lice" [liushi 六蟲]. All these are completely consistent with the ideological propositions of Mohism. By the time of Xunzi, there were "no Confucians"35 throughout Qin, as the Legalist ideology played a central role in its governance. Statesmen such as Han Fei 韓非 [ca. 28o-233 вCE] and $\mathrm{Li} \mathrm{Si}$ 李斯 [Ca. 28 o BCE-208 BCE] denounced Confucians as one of the "five vermin” [wudu 五蛽] and constantly questioned Confucius's words and deeds. They even went so far as to contend that "the emperor shall make decisions on all matters regardless of their severity" and adopted anti-Confucian policies aimed at "burning the books and burying the scholars." ${ }^{36}$ At this time, the attitude of the Qin Mohists toward Confucianism tended to merge with that of the Legalists from the Qin and Jin [1033-376 вСE] states. In this regard, we only need to look at the attitude of Mohism in the Han Fei zi and compare the "censuring" [jienan 詰難] of Confucius in the "Against Confucianism II" chapter in the Mozi to related content in the Han Fei zi to see that the two are consistent.

For example, in the Han Fei zi, the chapter "Collected Persuasions II [Shuolin xia 說林下]" says that Confucius once asked his disciples, "Who can tell me the way Zixi made his name?"37 This can be read as demonstrating Confucius's snobbish tendencies. Further, the chapter "Inner Assortment of

35 Wang Xianqian 王先謙, Xunzi jijie 荀子集解 [Collected Explanations of the Xunzi], coll. Shen Xiaohuan 沈嘯睘 and Wang Xingxian 王星賢 (Beijing: Zhonghua shuju, 1988), 304.

36 Sima Qian, Shiji, 325 .

37 Translation modified from W. K. Liao and Zhang Jue, Library of Chinese Classics: Han Fei Zi II (Beijing: Commercial Press, 2015), 623. - Trans. 
Parables I: The Seven Tactics" states that Confucius praised "the punishments of the late Shang dynasty for dumping ashes on the road," which demonstrates that Confucius advocated severe legal penalties. The chapter "Criticisms of the Ancients I [Nanyi 難一]” says: “How reasonable it must be that Duke Wen became hegemonic ruler!' Zhongni, when making this remark, did not know the right way to reward people." ${ }^{38}$ Likewise, the chapter "Criticisms of the Ancients II" states: "After he [King Wen] had waged these three campaigns, King Zhou came to dislike him. Afraid thereof, he offered to present the King with the land to the west of the Luo river and the country of the Red Soil, all together a thousand square $l i$ in area, and asked him to abolish the punishment for climbing the roasting pillar." This contends that Confucius's praise of King Wen's punishment was excessive. Lastly, the chapter "Criticisms of the Ancients III” criticizes Confucius for describing the exchange between Lord Ye 葉公 [ca. 550-47О ВСE] and Lord Ai of $\mathrm{Lu}$ 魯哀公 [r. 494-468 BCE] on governance as "state-ruining sayings." 39 Thus, it appears that the censuring of Confucius in the first half of "Against Confucianism II" transpired during the controversy between Confucianism and Mohism in the late Warring States period. It may even have arisen at the confluence of legalism and Mohism around the time that Qin unified China - specifically, not long before Kong Fu 孔鮒 [ca. 264-208 BCE] wrote the chapter "Interrogating Mohists" in the Anthology of the Kong Family Masters.

\section{The Mohist Critique of Daoism}

The motivations of the Mohists are depicted in the preceding paragraphs from the perspective of "valuing frugality." However, this ideological stance is not unique to the Mohists; other pre-Qin schools shared this tendency. Consider, for instance, Daoism in the pre-Qin period. Chapter 65 in the Laozi says: "I have three treasures that I keep with me: one called kindness, the second frugality, and the third fear of being the first in the world." ${ }^{40}$ Here, frugality

38 Translation modified from Liao and Zhang, Library of Chinese Classics, 4:1487. - Trans.

39 Translation modified from W. K. Liao and Zhang Jue, Library of Chinese Classics, 4:1581. - Trans.

40 Wang Bi 王㟲, annot., Lou Yulie 樓宇烈, coll., Laozi Daodejing zhu jiaoshi 老子道 德經註校釋 [Commentary and Collated Annotations on Laozi's Daodejing] (Beijing: Zhonghua shuju, 2008), 170. Translation modified from Zhao Yanchun 趙彥春, Daodejing yingyi 道德經英譯 [An English Translation of the Daodejing] (Beijing: Gaodeng jiaoyu chubanshe, 2018), 96. - Trans. 
is regarded as one of the "three precious things" [sanbao 三寶]. At least during the formation of the various chapters in the Mozi, Mohism absorbed some ideas from Daoism. The chapter “Lie Yukou 列禦寇” in the Zhuangzi states that when Zhuangzi's death was imminent, his disciples wished to hold an elaborate funeral, to which Zhuangzi responded: "From above, the crows and eagles will eat me; below, the ants will eat me: to take from one and give to another would only show your partiality."41 The two are not all that different, and an "elaborate funeral" has little meaning. What Zhuangzi had to say about simple burials is strikingly similar to that of Mozi. This shows that they both accepted and rejected Daoism as they deemed fit.

Describing the dispute between Confucians and Mohists, the "Boundless Discourses" chapter in the Huainanzi states: "The concepts of universal love, exalting worthiness, reverence for the ghosts, and opposition to fatalism were all advocated by Mozi, but Yangzi was opposed to them."42 Some have claimed that Mozi was criticizing Confucians, but the object of Mozi's criticism was not a particular individual but, rather, the opposing ideas espoused by Yangzi. Because, during the scholarly contention between Yangzi and Mozi, Yangzi targeted Mozi and Mohist ideas, so it is unlikely that Mozi and Mohism would promote their views and turn a deaf ear to the criticisms of Yangzi and his followers about their views. On the contrary, they would have launched a counterattack against the Yang school as directly as possible.

The extant version of the Liezi 列子 includes a chapter called "Yang Zhu 楊朱” that outlines the thought of Yangzi. Its authenticity has long been subject to dispute. However, as pointed out by Hu Shi 胡適 [1891-1962], "It seems that the chapter 'Yang Zhu' was compiled from various ancient sources with the aim of rebuilding the lost text,"43 Liang Qichao 梁啟超 [1873-1929] believed, "This chapter appears to be generally reliable." ${ }^{4}$ In the "Yang Zhu" chapter, Yang Zhu's ideological claim on the aforementioned ideas seems to be the opposite of that of Mozi, and the difference between Qin Guli 叐滑嶅 [470-40O BCE] and Yang Zhu is also seen there. This shows that Mozi's tendency to "refute Yang" at that time was not fictitious.

41 Guo Qingfan, Zhuangzi jishi, 1063. Translation modified from James Legge, The Sacred Books of China (Oxford: Clarendon Press, 1879), 1-2:38. - Trans.

42 Liu Wendian, Huainan honglie jijie, 524.

43 Hu Shi, Zhongguo zhexue dagang, 126.

44 Liang Qichao 梁啟超, Laozi, Kongzi, Mozi ji qi xuepai 老子、孔子、墨子及其學派 [Laozi, Confucius, Mozi, and Their Schools of Thought] (Beijing: Beijing chubanshe, 2016), 272. 
It is also notable that Yang Zhu inherited and developed the Laozian theory of health preservation. The chapter "Duke Wen of Teng II [Teng Wen Gong xia 滕文公下]" in the Mencius 孟子 says, "Yang Zhu's advocacy for self-preservation showed disregard for the ruler."45 The chapter "Fathoming the Mind I [Jinxin shang 盡心上]" comments on the same idea: "Yangzi's chief concern is the self; if pulling out a single hair could benefit the empire, he would not do it."46 The chapter "Avoiding Duplicity [Bu'er 不二]" in the Spring and Autumn Annals [Chunqiu 春秋] notes that "Yang Zhu valued the self." ${ }^{2}$ However, although these quotations demonstrate Yang's interest in egotism, it should be noted that he did not advocate benefiting oneself at the expense of others. This is because he valued the "integrity of the self" [cunwo 存我] while considering “attacking others" [qinwu 侵物] to be the most ignoble use of force. ${ }^{48}$ The "Yang Zhu" chapter in the Liezi says, "A man of ancient times, if he could have benefited the empire by the loss of one hair, would not have given it; and if everything in the empire had been offered to him alone, would not have taken it. When no one would lose a hair, and no one would take advantage of the empire, the empire was in good order."49 This quotation can be seen as representing the essence of Yangzian thought. ${ }^{50}$

Therefore, Yang Zhu's ideological proposition should be read as a Daoist health preservation method in the pre-Qin period. The Laozi urges readers to "maintain a pure and simple nature and reduce selfish desires and distracting thoughts. ${ }^{51}$ As mentioned previously, it also expounds on the importance of the "three treasures." It is easy to conclude that the Laozian means of survival simply involves minimizing personal desires, never thinking of oneself, and retiring to lead a life of seclusion, but interpretation demonstrates many misunderstandings. At the very least, it unintentionally or otherwise ignores Laozi's dialectic thought. Although Laozi did emphasize selflessness and inaction, they should be seen as the means, rather than the ends. The Laozi provides an explicit explanation of the necessity of these concepts in its contention that "a sage does not accumulate." It explains: "They

\footnotetext{
45 Jiao Xun 焦循, Mengzi zhengyi 孟子正義 [The Correct Meanings of the Mencius], coll. Shen Wenzhuo 沈文倬 (Beijing: Zhonghua shuju, 1987), 456.

46 Jiao Xun, Mengzi zhengyi, 915.

47 Chen Qiyou 陳奇猷, coll., Lüshi chunqiu jiaoshi 呂氏春秋校釋 [Collation and Annotation of Master Lü's Spring and Autumn Annals] (Shanghai: Xuelin chubanshe, 1995), 1127.

48 Translation modified from A. C. Graham, The Book of Lieh-tzu: A Classic of Tao (New York: Columbia University Press, 1990), 153. - Trans.

49 Translation modified from Graham, The Book of Lieh-tzu, 148. - Trans.

50 Hu Shi, Zhongguo zhexue dagang, 129.

51 Wang Bi, Laozi Daodejing zhu jiaoshi, 45 .
} 
have made themselves richer by helping others; they have made themselves more abundant by giving to others," and they "decrease, then decrease again until they reach the point of inaction; if you can do nothing, there is nothing you cannot do."52 Thus Laozian "eschewing of desire" [quyu 去欲], "selflessness" [wusi 無私], “considering the body as extraneous" [waishen 外身], and “inaction" [wuwei 無為] actually result in more desire, greater self-interest, and more action, so that "nothing is done yet nothing is left undone." Further, Yang Zhu's advice to "action in one's self-interest" [weiwo 為我] and "to value the self" [guiji 貴已] might appear to be manifestations of extreme self-interest but are actually equivalent to the Laozian concepts of purity and eliminating desire. In this sense, Mozi's criticisms of Yang Zhu's ideas might not necessarily be regarded as criticisms of pre-Qin Daoism and Laozian doctrine per se.

The "Universal Love [Jian'ai 兼愛]" chapter in the Mozi attacks people who are introduced as "certain scholars in the empire today" and "based on the words of the scholars of the empire who oppose universal love...." ${ }^{53}$ According to the "Boundless Discourses" chapter in the Huainanzi, what is referred to here is none other than the egotistical concepts of Yang Zhu. The Mozi shows that the antonym of "universal" [jian 兼] is “distinct" [bie 別] as in “distinguishing officers" [bieshi 別士]. The Mozi reads: “[They] arise from hating people and harming people" and that, "If we were to distinguish and name those in the world who hate people and harm people, would it be 'universal' or would it be 'discriminating'? We must undoubtedly say it would be 'discriminating."'54 Thus Mozi came to the conclusion that mutual discrimination, as the source of the world's great harms, "is to be condemned." 55 This demonstrates that Mozi's criticism of discrimination primarily focused on it in comparison to universality.

Liang Qichao believed that the concept of universality discussed in the Mozi was relative to the concept of discrimination. He argued, "According to Mozi, discrimination and universality were relative, just as Confucianism was criticized by other schools as 'discriminating." 56 Here Liang used the criticism of Yang Zhu's notion of egotism by Mencius to examine the criticism and countercriticism of Mozi and Yangzi, rather than using the positions of Mozi and Yangzi themselves to examine the mutual opposition of the two schools. In

\footnotetext{
$5^{2} \quad$ Wang Bi, Laozi Daodejing zhu jiaoshi, 192, 127.

53 Sun Yirang, Mozi jiangu, 102, 116.

54 Translation modified from Ian Johnston, The Mozi: A Complete Translation (Hong Kong: Chinese University Press, 2010), 147. - Trans.

55 Sun Yirang, Mozi jiangu, 113 .

56 Liang Qichao 梁啟超, Xianqin zhengzhi sixiangshi 先秦政治思想史 [A History of the Political Thought of the Pre-Qin Period] (Shanghai: Shanghai guji chubanshe, 2014), 126.
} 
fact, Yang Zhu's opposition to Mozi's idea of universal love did not equal the Confucian concept of "differing degrees of love." Rather, it was the Mohist concept of universal love, as opposed to "self-love" [zi'ai 自愛]. Thus, the "Universal Love" chapter explains that "universal love brings universal benefits" and that one must "strive for the benefit of the empire and seek to eliminate all calamities throughout it." Consider as well the following passage: "A son loves himself but not his father, thus hurting his father's self-interest; a younger brother loves himself but not his elder brother, thus hurting his brother's self-interest; a minister loves himself but not his ruler's self-interest, thus hurting the ruler's self-interest." ${ }^{57}$ In other words, self-love and self-interest involve the distinctions in love, rather than its universality, and it is this rather than the differing degrees or sequential order of love that was criticized by the Mozi.

Yang Zhu's concept of egotism has been interpreted in a variety of ways. Han Fei saw it as if Yang, by merely pulling out a hair, could enjoy the greatest benefit in the world. Mencius believed that Yang refused to pull out a single hair even if it would benefit the world. In fact, both of these readings are based on the premise that a person's life is most vital and that everything in life is done for the purpose of health preservation or self-cultivation. In other words, as the modern philosopher Feng Youlan 馮友蘭 [1895-1990] pointed out, "The body is the subject; everything is done for it. A person's body is the person's 'me'; to be for oneself is to be 'for me." 58 Yang believed society would remain orderly as long as everyone insisted on not losing a single hair for its benefit. Therefore, individuals must practice self-love and pursue self-interest. Because this is in direct opposition to Mozi's plan for peaceful governance based on the concept of universal love and benefiting others, it inevitably became the subject of Mohist criticism.

"Exalting Worthiness [Shangxian 尚賢]," parts I, II, and III, in the Mozi argues that men of proficiency and high caliber should be valued like treasures and seen as the foundations of good government. To put this into action, Mozi urges that they be "enriched, honored, revered, and commended." The chapter also criticizes those who fail in this endeavor, accusing those who overlook the capable as "seeing only the small picture and ignoring the larger one." In the words of Mozi, "The rulers of today speak of exalting the worthy in their daily life." As the Qing dynasty philologist Sun Yirang 孫詒讓 [1848-1908] pointed out, "It is not just Mozi who spoke of this." ${ }^{59}$ Before Mozi, however, only Laozi expressed overt opposition to exalting worthiness. He argued,

57 Sun Yirang, Mozi jiangu, 98-99.

$5^{8}$ Feng Youlan, Zhongguo zhexueshi xinbian, 187-88.

59 Sun Yirang, Mozi jiangu, 44-66. 
"People follow the Earth, the Earth follows the Heavens, the Heavens follow the Cosmic Way, and the Cosmic Way follows Nature." ${ }^{\prime 60}$ With this in mind, the theories of humaneness, dutifulness, rites, and wisdom should be abandoned and replaced with the practices of not knowing and not desiring. Chapter 3 in the Laozi explains why worthiness should not be exalted and makes the case for "government through inaction." 61 Liang Qichao argued that Mozi's opposing views on these topics "were all reactions to Laozi." ${ }^{2}$ After Laozi, Zhuangzi, a Daoist, and Shang Yang and Han Fei, who were Legalist, all supported Laozi's views on these matters. However, because they all came after Mozi, the chapter "Boundless Discourses" in the Huainanzi only recorded Yang Zhu as opposing Mozi's thoughts on exalting worthiness. This demonstrates that Mozi's criticism of the practice of not exalting worthiness at the time was clearly directed at Yang Zhu. Yang Zhu was a disciple of Laozi and, as such, inherited his master's views on nature [ziran 自然], which he then developed into a theory on extreme egotism. With this in mind, how could it be possible for Yang not to oppose Mozi's proposal to enrich, honor, revere, and commend the worthy, so as to induce them to contribute their talent and wisdom? Given that Yang Zhu was opposed to exalting worthiness, that the "Exalting Worthiness" chapter in the Mozi critiques his views should not be surprising.

The chapter "Perceptive Ghosts [Minggui 明鬼]" in the Mozi is divided into three parts, of which only part 3 is extant. It attempts to prove the existence of ghosts and spirits using theory and historical fact while denying and refuting their potential nonexistence. ${ }^{63}$ These positions are both opposite and complementary to each other. At the time of Mozi, although Confucius and his followers "did not speak on oddities, violence, turmoil, or ghosts and spirits" 64 and held the attitude that "ghosts should be revered but kept at a distance," ${ }^{n 5}$ there is no record of their completely denying their existence. Thus Confucius also said, "If I do not make an offering as if the spirits were present, it is as if I have not made the offering at all." ${ }^{66}$ Further, although the "Against Confucianism" and "Gong Meng" chapters in the Mozi accuse Confucians of believing that poverty, wealth, longevity, and untimely death are preordained, that the heavens are unintelligent, and that ghosts do not have spiritual powers, they also point out the internal contradiction that Confucians teach

\footnotetext{
6o Wang Bi, Laozi Daodejing zhu jiaoshi, 64.

$61 \quad$ Wang Bi, Laozi Daodejing zhu jiaoshi, 8.

62 Liang Qichao, Laozi, Kongzi, Mozi ji qi xuepai, 159.

63 Sun Yirang, Mozi jiangu, 221.

64 Zhu Xi, Sishu zhangjujizhu, 98.

65 Zhu Xi, Sishu zhangju jizhu, 89.

66 Zhu Xi, Sishu zhangju jizhu, 64.
} 
people to engage in study while believing that fate exists, and that ghosts and spirits do not have power while making offerings to them. ${ }^{67}$ It is evident that the supposedly Confucian beliefs that spiritual beings do not exist and that life is preordained were not sufficiently grounded and thus cannot serve as areas for Mohist criticism.

A case can be made that the only pre-Mohist tendency that supported atheism was Daoism. Chapter 6o in the Laozi says, "Ghosts and spirits have no effect when the Cosmic Way guides the governance of the empire."68 Laozi, a Daoist, began to see people and their essence as manifestations of "vital energy" [ $q i$ 氣], which left even less room for talk of the divine. The chapter "Inward Training [Neiye 內業]" in the Guanzi 管子 states: "The essence of all things, once combined, possesses vitality." It also says: "When we speak of essence we speak of the quintessence of vital energy. Vital energy generates life. With life there is thinking. With thinking there is cognition. With cognition we reach the boundary.... To be able to acclimatize to things and master their changes is to attain spirituality. To be able to adapt to ever-changing situations and master their changes is to attain wisdom."69 In the chapter "Great Bliss [Zhile 至樂]" in the Zhuangzi, the Master comments on his wife's death: "And yet, from the beginning, she had no life. Not only no life - she had no form. Not only no form - she had no spirit. From the original fuzzy state, that something became the energy of primal chaos. That energy then acquired a form. That form then acquired life. Now, like the cycling of the seasons, it has changed into death."70 This is none other than a total refutation of the existence of ghosts and spirits by Zhuangzi. Yang Zhu was the first to argue against the proposal by Mozi that spiritual beings be revered and disagreed with his theories on Heaven's intention and perceptive ghosts. Moreover, the person described as refusing to believe in the existence of ghosts whom Mozi criticized and refuted when establishing his theory of perceptive ghosts must have been Yang Zhu or at least someone like him.

When Mohist opposition to fatalism is discussed, the following saying by Confucian is often mentioned: "Life and death are determined by one's lot; wealth and poverty are determined by divine will." ${ }^{71}$ However, as the modern historian of philosophy Zhang Dainian 張岱年 [1909-2004] pointed out, “The

\footnotetext{
67 Sun Yirang, Mozi jiangu, 458, 454.

68 Wang Bi, Laozi Daodejing zhu jiaoshi, 157.

69 Li Xiangfeng 黎翔鳳, Guanzi jiaozhu 管子校注 [Collated Commentaries on the Guanzi], coll. Liang Yunhua 梁運華 (Beijing: Zhonghua shuju, 2004), 931, 937.

70 Guo Qingfan, Zhuangzi jishi, 614-15.

71 Zhu Xi, Sishu zhangju jizhu, 134.
} 
followers of Daoism talked about fate more than the Confucians did." ${ }^{72}$ Laozi and Zhuangzi both saw the carefree acceptance of predestination as the highest form of virtue. Chapter 16 in the Laozi says: "Things thereabout and therein return to their origin. 'Returning to origins' is called calmness, and calmness is called 'coming back to life,' 'coming back to life' is called nature, and nature is called "being in the light."'73 Zhuangzi even pushed this kind of fatalism to an extreme. For example, the chapter "Webbed Toes [Pianmu 駢拇]" in the Zhuangzi says: "Those who follow the correct standard do not digress from the facts of the nature of a thing and its destiny," and, later, "The kind of perfection of which I speak is not humaneness but, rather, the complete realization of the true nature of things." Likewise, the chapter "Running of Heaven [Tianyun 天運]" states: "Sageliness is nothing other than knowing the truth of things and following fate," and, later, "Nature cannot be changed. Destiny cannot be altered. Time cannot stop. Wide roads cannot be blocked." Lastly, the chapter "Achievement of Life [Dasheng 達生]" says: "People who know the truth about fate will not try to pursue that which is not meant to be."74

In these passages, fate is conceived of as an immutable law of nature with which people have no choice but to comply. It can be argued that Yang Zhu, like Zhuangzi, assimilated the Laozian concept of "resignation to fate" [tingming 聽命] and the theory of predestination. As a result, he came under fire from Mozi, who regarded him as one of "those who hold that there is fate."

\section{Mohist Criticism of Other Pre-Qin Philosophies}

Mozi was more or less contemporaneous with Confucius. Both were active at the end of the Spring and Autumn period $[770-476 \mathrm{BCE}]$ and the beginning of the Warring States period. Confucius was the founding master of the pre-Qin philosophers. Although Mozi explicitly criticized Confucianism and Daoism, he could not have critiqued schools that were not yet mature, such as the school of yin-yang, the school of diplomacy [zongheng 縱横], legalism, the school of logic, the school of agriculture [nong 農], and syncretism [ $z a$ 雜]. However, links can be found between Mohism and those schools of thought because Mohism emerged first, so it influenced the intellectual tendencies of

72 Zhang Dainian 張岱年, Zhongguo zhexue dagang 中國哲學大綱 [An Outline of Chinese Philosophy] (Beijing: Zhonghua shuju, 2017), 513.

73 Wang Bi, Laozi Daodejing zhu jiaoshi, 35-36. Translation modified from Zhao Yanchun, Daodejing yingyi, 49. - Trans.

74 Guo Qingfan, Zhuangzi jishi, 155, 199, 317, 327, 507, 532, 63 o. 
those that followed in varying degrees. This has given rise to the argument that many schools are Mohist in origin.

For example, with respect to the school of yin-yang, the chapter "Refusing Extravagances [Ciguo 辭過]" in the Mozi mentions it. The modern historian Meng Wentong 蒙文通 [1894-1968] states, "Mohism held ghosts in high esteem, while the school of yin-yang denied human agency and put themselves at the mercy of ghosts." ${ }^{75}$ The chapter "Valuing Righteousness [Guiyi 貴義]" in the Mozi records a conversation between Mozi and a soothsayer: "Further, on jia and yi days, the Yellow Thearch kills the Azure Dragon in the east; on bing and ding days, the Red Dragon in the south; on geng and xin days, the White Dragon in the west; and on ren and gui days, the Black Dragon in the North."76 This demonstrated that not only did Mozi speak of the school of yin-yang, but it was the first time in China's intellectual history that the five elements [wuxing 五行] were matched with the five Thearchs [wudi 五帝], five positions [wufang 五方], and five periods [wushi 五時].

Another case in point is the school of logic. The "Geng Zhu" chapter in the Mozi states that Zhitu Yu 治徒娛 and Xian Zishuo 縣子碩 asked Mozi, "What is the most important aspect of practicing righteousness," to which the Master replied,

It is like building a wall. Those who are able to compact the earth should compact it; those who are able to carry the earth should carry it; those who are able to do the survey should do it. Then the wall will be completed. Practicing righteousness is like this. When those who are able to dispute, dispute; when those who are able to explain the writings, explain them; when those who are able to conduct affairs, conduct them - then righteousness will be complete. ${ }^{77}$

This demonstrates that, at the time of Mozi, although the School of Logic may not have become an official pre-Qin philosophy, its dialectical tendencies had already formed, and Mozi acknowledged the value and significance of debate, believing it to be crucial in practicing righteousness. Thus, although Mozi's own utterances were "so filled with words that his message at times was obscured,"78 undoubtedly he still appreciated the practice of proper rhetoric.

75 Meng Wentong 蒙文通, Guxue zhenwei 古學甄微 [Subtle Inquiries in Classical Studies] (Chengdu: Bashu shushe, 1987), 312.

76 Sun Yirang, Mozi jiangu, 448 .

77 Sun Yirang, Mozi jiangu, 426-27. Translation modified from Johnston, The Mozi, 643. - Trans.

78 Liang Qixiong, Hanzi qianjie, 272. 
Chapters in the Mozi such as "Geng Zhu," "Valuing Righteousness," "Gong Meng," “Lu's Questions [Luwen 魯問]," and "Gongshu 公輸” record Mozi's debates with others and his "analysis of principles" [xili 析理] by "distinguishing names” [bianming 辨名]. Therefore, the debates recorded in the Mozi mostly show rigorous logic. Past scholars have already explained this in detail, but here an example is given to clarify it. The "Gongshu" chapter in the Mozi records the Master's meeting with King Hui of Chu 楚惠王 [r. 488-432 BCE]. Mozi used rigorous reasoning to demonstrate the injustice of Chu's [1115-223 BCE] attack on the Song [1114-286 BCE]. Not only is it strongly persuasive logically, but it also demonstrates that he is worthy of being considered the great founder and practitioner of logic in China. Later, Mohist logicians had outstanding intellectual achievements, giving rise to the assumption that the scholars at the school of logic had Mohist origins. This result is due to all kinds of complex historical factors.

Later followers of Mohism were generally called neo-Mohists [biemo 別墨], as they were passionate debaters about the "separation between hard and white" [lijianbai 離堅白] and the "unity of sameness and difference" [hetongyi 合同異], among other concerns. ${ }^{79}$ The theoretical achievements of neo-Mohists in terms of their study of logic are mostly recorded in the chapters "Choosing the Greater [Da qu 大取], "Choosing the Lesser [Xiao qu 小取]," "Canons [Jing 經]," and "Explanations [Jingshuo 經說]." The scholar Lu Sheng 魯勝 in the Western Jin 西晉 [266-316] referred to them as "Mohist dialectics" [mobian 墨辯]. Some scholars have argued that these dialectic chapters were developed before Hui Shi 惠施 [370-310 BCE] and others and that Hui Shi refuted their views. ${ }^{80}$ If this view were reversed, the "hard and white and sameness and difference" discourse in the Mohist dialects could be regarded as disagreement and controversy caused by Song Xing 宋釬 [37O-291 BCE] and Hui Shi and that the "containing hard and white" and "unity of sameness and difference" factions among the neo-Mohists were criticisms of the "separating hard and white" and "distinguishing sameness and difference" groups such as those of Hui Shi and Gongsun Long 公孫龍 [ca. 320-25O BCE]. This might be closer to the actual development of Mohism in the mid-Warring States period. ${ }^{81}$ According to the research of scholars such as Guo Moruo 郭沫若 [1892-1978], the chapters “Canons" and "Explanations"

79 Guo Qingfan, Zhuangzi jishi, 1079.

8o Yang Kuan 楊寬, Zhanguo shi 戰國史 [A History of the Warring States Period] (Shanghai: Shanghai renmin chubanshe, 2003), 573 .

81 Gao Huaping 高華平, Xianqin zhuzi yu chuguo zhuzi xue 先秦諸子與楚國諸子學 [Research on the Philosophers of the Pre-Qin Period and the Domain of Chu] (Beijing: Beijing shifan daxue chubanshe, 2016), 223-27. 
can be read as expounding on two mutually opposing factions. Guo notes that "Canons I" advocates "containing hard and white," whereas "Canons II" supports "separating hard and white." He then argues that the view on sameness and difference as discussed in "Canons I" is based on common sense, whereas that of "Canons II" carries forward the views of Hui Shi. ${ }^{82}$ Thus, the criticism of neo-Mohism present in the Mohist canons can be regarded as the criticism of one group of Mohists and of Hui Shi and others by later Mohists.

Legalism is another case in point. It formed before the Qin but after Mohism, so it would not have been possible for early Mohists to criticize its ideas. However, the term $f a$ is mentioned many times in the Mozi. As a verb that means "to follow the example of," $f a$ is used in the chapter "On Standards and Rules [Fayi 法儀]" as "to take one's father and mother as one's model" and "to pattern the Heavens." As a noun meaning "rule," "law," or "standard," it is seen in the chapter "Heaven's Intention II [Tianzhi zhong 天志中]”: “Therefore, Mozi believed that there was such a thing as Heaven's intention.... Therefore, roundness and nonroundness are both available and knowable. What is the reason for this? It is because the rules for determining the circle are very clear." The chapter also states, "Therefore, Mozi conceived of Heaven's intention and regarded it as the basic standard." 83 This shows that the word $f a$ in the Mozi often referred to rules, laws, or standards, a usage that differs from that of legalism, which usually used $f a$ to refer to penalties and decrees. Yet Mohists' emphasis on $f a$ and all the ideological principles and methods that flow from it are nonetheless consistent with legalism. That the Legalists took their name from the term $f a$ can be said to be the result of their having been inspired by Mohist thought. It can also be said that Mohists were influenced by the concept of "exalting the law" [shangfa 尚法], espoused by early Legalists.

Further, the chapter "On Standards and Rules" states, "Mozi said: People who handle affairs in the world cannot be without rules. A matter has never been settled without rules. Even if a scholar becomes a high-ranking officer or chancellor, he must have laws. Even craftsmen working in various industries have laws." The chapter "Exalting Unity II [Shangtong zhong 尚同中]" says: "Everyone in the world has different opinions. So one person has one opinion, ten people have ten opinions, and a hundred people have a hundred opinions. The higher the number, the more opinions. Because everyone thinks that their opinions are right, and that others' opinions are wrong, they attack

82 Guo Moruo 郭沫若, Shi pipan shu 十批判書 [Ten Books of Criticism] (Beijing: Renmin chubanshe, 1954), 247-48.

83 Sun Yirang, Mozi jiangu, 21, 22, 205, 211. 
each other." 84 This argument may have directly inspired Legalists to unify their ideology and inhibit the development of other schools of thought.

Mohism's overt criticism of Legalist scholarship would have been expressed by the Song Xing and Yin Wen 尹文 [36o-280 BCE] factions of the Jixia Academy [Jixia xuepai 稷下學派]. After all, concepts such as "being insulted without being disgraced," "banning violence and suppressing warfare," and "keeping people from fighting" are typical of their thinking. So why did Song and Yin espouse ideological propositions of this nature? Obviously, they were articulated at a time when verbal debates were commonplace. Moreover, the most fervent advocates of warfare and fighting for personal honor were the pre-Qin Legalists. Therefore, the fiercest critics of Song and Yin's propositions were Xun Qing 荀卿 [ca. 310-235 BCE], who emphasized rituals and laws, and Han Fei, who epitomized the Legalist thought. The target of Song and Yin's criticisms was the utilitarian thought of Legalists, who were seen as fighting for their own fame and fortune.

The formation of minor pre-Qin intellectual trends such as the schools of diplomacy, agriculture, and syncretism occurred after the advent of Mohism. As a result, Mozi and early Mohists would not have had the opportunity to criticize them, and there is little relationship between them. Moreover, the Mohist concepts of universal love, condemnation of offensive warfare, and exalting unity were contradictory to the call by the school of diplomacy for "offense, defense, and annexation," "lobbying and debating," "switching sides," and "methods of deception and treating people unfairly." Thus, it can be said that the Mohist criticism of legalism was also, in a sense, a kind of criticism of the school of diplomacy. In the "Valuing Righteousness" chapter in the Mozi, the Master says, "I did not assume the post assigned to me by our ruler, nor did I have the trouble caused by farming." 85 This shows that he did not directly participate in agricultural labor. It is notable that Mozi fashioned birds out of bamboo and wood, and most of his disciples were also handicraftsmen. Naturally, he did not pay much attention to farmers and agricultural production. However, he resolutely maintained the social hierarchy at that time, so it is conceivable that Mozi and Mohism adopted a negative attitude toward the Agriculturalists, who proposed that the ruler cultivate the land with the peasants and take meals with them.

The chapter "Duke Wen of Teng I" in the Mencius says that Xu Xing 許行 (372-289 вСЕ) "had dozens of disciples, all dressed in hemp clothes, making

84 Sun Yirang, Mozi jiangu, 20, 77.

85 Sun Yirang, Mozi jiangu, 445 . 
a living by making straw sandals and weaving mats." 86 Some scholars believe that Xu Xing was a Mohist, but this is not accurate. As mentioned earlier, Mozi opposed the concepts of "one person, one opinion" and "one hundred people, one hundred opinions," so he would not have agreed with the viewpoints of the Syncretists. Rather, he would have advocated the unification of thought as proposed by the Legalists. The chapter "Perceptive Ghosts" in the Mozi speaks of King Xuan of Zhou 周宣王 [r. 828-783 BCE] being killed by an arrow fired by the ghost of Du Bo 杜伯 and myriad other classical allusions to prove the existence of ghosts. In the chapter "Evaluating Ghosts [Dinggui 訂鬼]" in Discourses Weighed in the Balance [Lunheng 論衡], the Han dynasty [206 BCE-220] philosopher Wang Chong 王充 [27-97] outlined his argument against the existence of ghosts. Modern scholars claim that these accounts in the Mozi were by the school of minor talks [Xiaoshuo jia 小說家]. However, the Mozi overtly states that they were recorded in classics such as the Book of Songs, the Book of Documents, and the Spring and Autumn Annals. Presumably, these classics were cited with the goal of demonstrating the credibility of his remarks. It has been suggested that Mozi believed that the school of minor talks "developed from talks on the street and legends on the road" 87 and thus could never achieve "grand elegance" [daya 大雅]. Thus, even if some sources in the school of minor talks could prove his arguments, Mozi would not use them. This can be read not only as Mozi's attitude toward the school but also as a Mohist criticism of it.

\section{Translated by Carl Gene Fordham}

\section{Works Cited}

Chen Guoqing 陳國慶, ed. Hanshu yiwenzhi zhushi huibian 漢書藝文志注釋彙編 [Commentaries and Elucidations on the Bibliographic Treatise of the History of the Han]. Beijing: Zhonghua shuju, 1983 .

Chen Qiyou 陳奇猷, coll. Lüshichunqiujiaoshi 吕氏春秋校釋 [Collation and Annotation of Master Lü's Spring and Autumn Annals]. Shanghai:Xuelin chubanshe, 1995.

Chen Zhu 陳柱. Moxue shilun 墨學十論 [Ten Essays on Mohist Scholarship]. Shanghai: Huadong shifan daxue chubanshe, 2015.

86 Ren Jiyu 任繼愈, Mozi yu mojia 墨子與墨家 [Mozi and Mohism] (Beijing: Beijing chubanshe, 2016), 4.

87 Chen Guoqing, Hanshu yiwenzhi zhushi huibian, 163. 
Chen Zhu 陳柱. Zhuzi gailun: Wai yi zhong 諸子概論: 外一種 [Introduction to the Pre-Qin Philosophers: An Additional Version]. Shanghai: Huadong shifan daxue chubanshe, 2015 .

Cheng Shude 程樹德. Lunyu jishi 論語集釋 [Collected Annotations on the Analects]. Collated by Cheng Junying 程俊英 and Jiang Jianyuan 蔣見元. Beijing: Zhonghua shuju, 1990.

Feng Youlan 馮友蘭. Zhongguo zhexueshi xinbian 中國哲學史新編 [A New Account of the History of Chinese Philosophy], vol. 1. Beijing: Renmin chubanshe, 2007.

Gao Huaping 高華平. “Mozi shengzunian xinkao 墨子生卒年新考 [New Studies on the Dates of Birth and Death of Mozi].” Jiangxi shifan daxue xuebao 江西師範大學學報, no. 5 (2018): 83-89.

Gao Huaping 高華平. Xianqin zhuzi yu chuguo zhuzi xue 先秦諸子與楚國諸子學 [Research on the Philosophers of the Pre-Qin Period and the Domain of Chu]. Beijing: Beijing shifan daxue chubanshe, 2016.

Graham, A. C. The Book of Lieh-tzu: A Classic of Tao. New York: Columbia University Press, 1990.

Guo Moruo 郭沫若. Shi pipan shu 十批判書 [Ten Books of Criticism]. Beijing: Renmin chubanshe, 1954.

Guo Qingfan 郭慶藩. Zhuangzi jishi 莊子集釋 [Collected Annotations on the Zhuangzi]. Collated by Wang Xiaoyu 王孝魚. Beijing: Zhonghua shuju, 2012.

He Bingdi 何炳棣. “Guoshi shang de 'dashi yinyuan' jiemi: Cong chongjian Qin-Mo shishi rushou 國史上的“大事因緣解謎一從重建秦墨史實入手 [Revealing the 'Causality of Major Events' in Chinese History: Starting with the Reconstruction of the Historical Facts Surrounding the Mohists in Qin]." Guangming ribao 光明日報, June 3, 2010, 10-11.

$\mathrm{Hu}$ Shi 胡適. Zhongguo zhexue dagang 中國哲學大綱 [An Outline of Chinese Philosophy]. Shanghai: Shanghai guji chubanshe, 1997.

Jiang Quan 江瑔. Duzi zhiyan 讀子厌言 [Incoherent Words on Reading the Masters]. Shanghai: Huadong shifan daxue chubanshe, 2012.

Jiao Xun 焦循. Mengzi zhengyi 孟子正義 [The Correct Meanings of the Mencius]. Collated by Shen Wenzhuo 沈文倬. Beijing: Zhonghua shuju, 1987.

Johnston, Ian. The Mozi: A Complete Translation. Hong Kong: Chinese University Press, 2010.

Legge, James. The Sacred Books of China, Volumes 1-2. Oxford: Clarendon Press, 1879.

Li Xiangfeng 黎翔鳳. Guanzi jiaozhu 管子校注 [Collated Commentaries on the Guanzi]. Collated by Liang Yunhua 梁運華. Beijing: Zhonghua shuju, 2004.

Liang Qichao 梁啟超. Laozi, Kongzi, Moziji qixuepai 老子、孔子、墨子及其學派 [Laozi, Confucius, Mozi, and Their Schools of Thought]. Beijing: Beijing chubanshe, 2016.

Liang Qichao 梁啟超. Xianqin zhengzhi sixiangshi 先秦政治思想史 [A History of the Political Thought of the Pre-Qin Period]. Shanghai: Shanghai guji chubanshe, 2014. 
Liang Qixiong 梁啟雄. Hanzi qianjie 韓子淺解 [A Brief Interpretation of the Han Fei zi]. Beijing: Zhonghua shuju, 20og.

Liao, W. K., and Zhang Jue. Library of Chinese Classics: Han Fei Zi. Beijing: Commercial Press, 2015.

Liu Wendian 劉文典. Huainan hongliejijie 淮南鴻烈集解 [Collected Explanations of the Huainanzi]. Collated by Feng Yi 馮逸 and Qiao Hua 喬華. Beijing: Zhonghua shuju, 1989 .

Lü Simian 呂思勉. Xianqin xueshu gailun 先秦學術概論 [Introduction to Pre-Qin Scholarship]. Changsha: Yuelu shushe, 2010.

Major, John S., Sarah A. Queen, Andrew Seth Meyer, and Harold D. Roth. The Huainanzi: A Guide to the Theory and Practice of Government in Early Han China. New York: Columbia University Press, 2010.

Meng Wentong 蒙文通. Guxue zhenwei 古學甄微 [Subtle Inquiries in Classical Studies]. Chengdu: Bashu shushe, 1987.

Ren Jiyu 任繼愈. Mozi yu mojia 墨子與墨家 [Mozi and Mohism]. Beijing: Beijing chubanshe, 2016.

Sima Qian 司馬遷. Shiji 史記 [Records of the Grand Historian]. Comments by Pei Yin 裴 馹, Sima Zhen 司馬貞, and Zhang Shoujie 張守節. Beijing: Zhonghua shuju, 2014.

Sun Yirang 孫詒讓. Mozi jiangu 墨子閒詁 [Inquiries and Interpretations of Mozi]. Collated by Sun Qizhi 孫啟治. Beijing: Zhonghua shuju, 2001.

Wang Bi 王斨, annot., Lou Yulie 樓宇烈, coll. Laozi Daodejing zhu jiaoshi 老子道德 經註校釋 [Commentary and Collated Annotations on Laozi's Daodejing]. Beijing: Zhonghua shuju, 2008.

Wang Pinzhen 王聘珍. Da dai liji jiegu 大戴禮記解詁 [Explanations and Philological Assessments of the Ritual Record of the Elder Dai]. Collated by Wang Wenjin 王文錦. Beijing: Zhonghua shuju, 1983.

Wang Xianqian 王先謙. Xunzi jijie 荀子集解 [Collected Explanations of the Xunzi]. Collated by Shen Xiaohuan 沈嘯寰 and Wang Xingxian 王星賢. Beijing: Zhonghua shuju, 1988.

Wu Yujiang 吳毓江. Mozi jiaozhu 墨子校注 [The Mozi with Collated Commentaries]. Collated by Sun Qizhi 孫啟治. Beijing: Zhonghua shuju, 2001.

Yang Kuan 楊寬. Zhanguo shi 戰國史 [A History of the Warring States Period]. Shanghai: Shanghai renmin chubanshe, 2003 .

Zhang Dainian 張岱年. Zhongguo zhexue dagang 中國哲學大綱 [An Outline of Chinese Philosophy]. Beijing: Zhonghua shuju, 2017.

Zhao Yanchun 趙彥春. Daodejing yingyi 道德經英譯 [An English Translation of the Daodejing]. Beijing: Gaodeng jiaoyu chubanshe, 2018.

Zhu Xi 朱喜. Sishu zhangju jizhu 四書章句集注 [Collected Commentaries on the Four Books Arranged in Sections and Sentences]. Beijing: Zhonghua shuju, 1983. 